\title{
Urban hydrological model (UHM) developed for urban flash flood simulation and analysis of sensitivity of flood intensity to urbanization
}

Haibo Hu ( $\sim$ hbhu@ium.cn )

Institute of Urban Meteorology, CMA

Xiya Zhang

Institute of urban meteorological, CMA

Chunlei Meng

Institute of Urban meteorology, CMA

Conglan Cheng

Institute of Urban Meteorology, CMA

Ying Wang

Beijing Normal University

\section{Research Article}

Keywords: flash flood, urban hydrological model, sensitivity

Posted Date: August 18th, 2021

DOI: https://doi.org/10.21203/rs.3.rs-756738/v1

License: (9) This work is licensed under a Creative Commons Attribution 4.0 International License.

Read Full License 


\title{
Urban hydrological model (UHM) developed for urban flash flood simulation and analysis of sensitivity of flood intensity to urbanization
}

\author{
HaiBo Hu, ${ }^{a}$ Xiya Zhang, ${ }^{a}$ Chunlei Meng, ${ }^{a}$ Conglan Cheng, ${ }^{a}$ Ying Wang ${ }^{b}$ \\ a Institute of Urban Meteorology, CMA, Beijing 100089, China \\ ${ }^{\mathrm{b}}$ Key Laboratory of Environmental Change and Natural Disaster of Ministry of \\ Education, Beijing Normal University, Beijing 100875, China
}

Corresponding author: Ying Wang,564469698@qq.com

\begin{abstract}
A two-dimensional raster gridded urban hydrological model has been developed to simulate the hydrologic response to urban land surfaces with consideration of the hydraulic characteristics of urban areas, and to produce mappings of urban inundation associated with rainstorms. The model is forced using radar-observed QPEs, in conjunction with parameter sets of land use and land cover (LULC) derived from satellite multispectral images and high spatial resolution GIS datasets relating to urban hydrology and land surface hydrodynamic properties. Urban drainage flow capacity is derived from a GIS road-network dataset using a generalization method. Submodels deduce runoffs of both the impervious and the pervious. Methodologically, the D8 method (eight slope directions) is used to derive the channel paths for gravity-driven nondispersive streamflow, which its hydrodynamics can be described by the hydraulic model based on simplified 1D - 2D St. Venant equation. A case study was undertaken to reproduce the urban flash flooding that occurred in Beijing following thunderstorms on 21 July 2012. The model results were verified qualitatively using media reports of the flooding. Through manipulation of model parameters, the test on the sensitivity of flash flood intensity to urban LULC variability and drainage network settings revealed the following: 1) flood intensity is enhanced slightly if the current urban LULC is substituted with a pure impervious, 2)
\end{abstract}


increasing the pervious surface area (PSA) attenuates flood intensity considerably, and 3) flash flood intensity will increase by $30 \%-60 \%$ in the absence of an underground drainage system.

Keywords: flash flood; urban hydrological model; sensitivity

Declarations: The work described in the paper has not been published previously (except in the form of an abstract or as part of a published lecture or academic thesis), that it is not under consideration for publication elsewhere, that its publication is approved by all authors and tacitly or explicitly by the responsible authorities where the work was carried out, and that, if accepted, it will not be published elsewhere including electronically in the same form, in English or in any other language, without the written consent of the copyright-holder.

\section{Introduction}

In recent years, many urban areas have been repeatedly striken by storms producing flash floods that have resulted in large numbers of human casualties and substantial economic losses (Zhou et al. 2013; Hu et al. 2015; Siswanto et al. 2015; Oldenborgh et al. 2016). Considerable research effort by meteor-hydrologists has focused on explaining the magnitude and frequency of urban flash flood occurrence (e.g., Graf et al. 1977; Bowling et al. 2000; Ogden et al. 2000; Smith et al. 2000; Beighley et al. 2003; Turner-Gillespie et al. 2003; Easton et al. 2007; Kotowski et al. 2013; Barthold et al. 2015; Bartsotas et al. 2017), determining effective flood mitigation measures (e.g., Gourley et al. 2005; Sharif et al. 2006; Haberlandt 2007; Smith et al. 2012; He et al. 2013; Morneno et al. 2013), and developing flash flood nowcast and warning systems for risk reduction (e.g., Sharif et al. 2006; He et al. 2013; Morneno et al. 2013).

Except for that climate change leads to greater climate and weather extremes (Allen and Ingram 2002; IPCC 2007; Wolter et al. 2016), the increasing frequency of urban flooding is considered related to land use and land cover (LULC) changes induced by urbanization, which also impacts on local weather and climate patterns 
(Shepherd and Burian 2003; Shepherd 2005; Yang et al. 2013; Hu 2015). The hydrologic response to urban LULC, characterized as the generation of greater runoff volumes and higher peak flow rates with reduced lag time, explains the susceptibility of urban areas to the flash flood occurrence (Smith et al. 2002; Yang et al. 2013). Moreover, obsolete urban drainage networks constructed following outdated design standards, which did not fully consider the impact of future climate change, have been becoming inadequate for the urban flash floods mitigation (Kotowski et al. 2013).

With reduction in vegetations retaining rainfall and the expanding impervious, urbanized areas are more prone than suburban and rural areas to the flash flood occurrence (Beighley and Moglen 2002; Smith et al. 2002, 2005a, 2005b). Sharif's (2006) striking example of "that on the same evening of the flash flood that devastated Fort Collins, Colorado, on 27 July 1997, a more intense storm occurred in rural Colorado with no reported injuries or significant damage," demonstrated the substantial role of urbanization in increasing the urban flash flood risk (Smith et al. 2002; Beighley et al. 2003; Turner-Gillespie et al. 2003; Smith 2005b; Easton et al. 2007; Yang et al. 2010; Ogden et al. 2011; Wright et al. 2011). However, the contribution of urbanization should be evaluated quantitatively and verified using long-term hydrometeorological observations (Easterling et al. 2000). This would help in choice of effective measures for urban flash flooding risk reduction, for example, substantially improving urban drainage systems (Li et al. 2019) and building the so-called "sponge cities" (or urban city resilience) (Yong et al. 2018; Yin et al. 2021).

Note that a lack of long-term hydrological data makes it impossible to explain the direct effects of urbanization on land surface hydrology based on hydrographs observed under different stages of urban development (Yang et al. 2012). However, when using short-term data, it cannot be ascertained whether any observed tendency is attributable to climatic variability or the urbanization effects on the hydrological process (Pielk et al. 2007; Yang et al. 2010). Pielk et al. (2007) suggested that solely analyzing flow variability in urban catchments would be insufficient to determine the effects of urbanization on regional hydrology. This is because urban hydrology can be 
characterized not only by LULC change but also by climatic change. Numerical model simulation can be crucial in quantitatively evaluating the effects of LULC change on urban hydrological characteristics and subsequently reveal any spatiotemporal hydrographic tendencies (Bowling et al. 2000; Pielk et al. 2007; Yang et al. 2010). Moreover, it can help evaluate the sensitivity of the land surface pattern with respect to flash flood occurrence. Smith et al. (2002) claimed that appropriate hydrological model simulation could adequately reflect urban hydrological variability and confirm the hydrological response under various LULC conditions (Yang et al. 2013).

Meanwhile, the urban drainage system plays an important role in flash flood risk reduction (Graf 1977; Li et al. 2019; Broekhuizen et al. 2020), which will be desired of being evaluated using model simulation. Graf (1977) recommended when assessing hydrological impacts of suburban developments, not only LULC changes but also drainage network changes should be equally taken into account. Except for the urban LULC properties correlated to hydrological variability, the urban drainage network also has a marked impact on the hydrological response (Turner-Gillespie et al, 2003; Broekhuizen et al. 2020). Therefore, the flow capacity of urban drainage system should be introduced in the hydrological modelling. However, its derivation can be a substantial challenge, especially in China where urban sewerage distribution data are not widely accessible. So we had to rely on substitute information and using a generalization method to derive the drainage flow capacity. Obviously, this derivation can induce uncertainty, and hence makes it necessary of validating the urban hydrological model (UHM) simulation and indirectly proving the rational of the derivation, though it represents a great challenge.

The challenge is that the model reproducing flash flood occurrences and inundation mappings can not be adequately validated based on dedicated observations (Herman and Schumacher 2018), i.e., checking for whether the model results being in good agreement with the "true" inundation depths, dimensions and durations during the flood events (Assumpção et al. 2018; Sy et al. 2020). It is due to no sufficient observation source (e.g., hydrographical data) available to verify the flash flooding 
occurrence, especially in urban areas with no gauge measurements (Amponsah et al. 2016; Borga et al. 2007;Herman and Schumacher 2018). Thus, postevent surveys, in situ photos, and media reports of flash flooding events (e.g., from newspapers and Internet websites), as well as interviews with local residents (Borga et al. 2007; Sy et al. 2020), are necessary for model validation and comparison with model simulation results. This approach, called "civil science" by Assumpção et al. (2018), which is currently the only plausible option for verification in this case, is devoted to qualifying the UHM for urban flash flood warning and risk recognition.

Following section 2 introduces the data derivation, the methodology used to generalize the drainage flow capacity index, and the UHM parameterization. Section 3 presents the UHM fundamentals and the methods used to deduce runoff, channel path routing, and hydraulic processing represented by the St. Venant equation. Section 4 introduces a case study on the Beijing "7.21" rainstorm, and analyzes the hydrologic response to urban LULC and drainage network changes based on model simulation scenarios. Finally, our conclusions are presented in section 5.

\section{Data derivation and generalization for UHM application}

\subsection{Forcing data of radar rainfall estimates}

Radar-derived QPEs/QPFs are data sources commonly used for forcing hydrological models because of their specific spatiotemporal resolution and larger areal coverage in comparison with gauge rainfall data (Steiner et al. 1995; Ciach et al. 1997; Gourley and Vieux 2005; Villarini et al. 2008; van de Beek et al. 2010; Xin et al. 2013). Thus, we used the QPE/QPF datasets of the Auto-Now-Casting (BJ_ANC) system from the Beijing Meteorology Bureau as the forcing data resource.

Since 2005, the BJ_ANC system has synchronously received the observations from three WSR-88D radars deployed at the Guangxiangtai, Tanggu and Zhangbei meteorological stations. The system produced QPEs/QPFs on series of radar merge images $(600 \times 600$ pixels $)$ with $1 \times 1 \mathrm{~km}$ spatial resolution in a 6 -min radar volume scanning interval (Chen et al. 2013). After 2007, additional two radars located at the 
Chengde and Shijiazhuang meteorological stations in Hebei Province participated in delivering radar observations to the BJ_ANC. Since then, the system has begun to produce $800 \times 800$ pixels $\mathrm{QPEs} / \mathrm{QPFs}$ imageries that spatially cover the entire Beijing domain.

The radar rainfall estimations are performed remotely and indirectly, and its signal is often contaminated with various types of noise and artifact; therefore, it is recommended that the rainfall estimates be tuned using gauge rainfall data for bias correction (Smith and Krajewski 1991; Anagnostou and Krajewski 1998; Seo and Breidenbach 2002; Haberlandt 2007). Thus, from 2012, the QPEs have been corrected using quality-controlled precipitation observations from almost 2000 manned/automated rain gauges in the radar observable ranges (Zhang et al. 2015). The adjustment method suggested by He et al. (2013) is used in the QPEs bias correction procedures, which make the QPEs more qualified for forcing hydrological models (Smith et al. 2012; Wright et al. 2012; Yang et al. 2013). Furthermore, the 1-, 3-, and 6-h QPFs are also modified using nonhydrostatic high-resolution NWP model rainfall fields, for which a blending technique is taken to connect the nowcasting and the meteorological model results to produce a radar rainfall forecast having improved accuracy both in rainfall magnitude and location (Golding 1998; Kober et al. 2012; Atencia et al. 2010; Kilambi and Zawadzky 2005; Nerini et al. 2018).

Before use in forcing the hydrological model, the QPEs/QPFs are downscaled from their original 1-km Cartesian grids to the 30-m hydrological model grid cells using the inverse distance weighting interpolation method, and equivalently calibrated to the DEM used by the UHM.

\subsection{LULC derivation}

The high-resolution (30 m) Globe Land Cover Data product (GlobeLand30) for 2010, provided by the National Geomatics Center of China, was used to extract the impervious surface area (ISA) within the study region. GlobeLand30 data are produced mainly from Landsat TM/ETM+ imagery. Images from the Chinese HJ-1 Environmental and Disaster satellite are also used as supplementary data for 2010 
(Chen et al. 2014). Additionally, various other image data useful for classification and validation are collected, including MODIS NDVI data, Global Geometrics data, Global DEM data, and online high-resolution images (e.g., Google Earth, Bing, and OpenStreet images). GlobeLand30 has 10 land cover types: cultivated land, forests, grasslands, shrublands, wetland, water bodies, tundra, artificial surfaces, permanent snow and ice, and barren lands. However, the ISA and pervious surface area (PSA) should be subclassified in the cells and certain GlobeLand30 LULC subclassifications cannot satisfy the needs regarding configuration of the surface hydrological and hydrodynamic properties (see Tables 2, 4, and 5). Thus, we introduced 1:2000 high-resolution GIS datasets mapped in 2010, which are provided by the Beijing Surveying and Mapping Bureau, to derive the LULC classifications/subclassifications in the 30-m cells using a GIS overlapping operator. The distribution of the imperviousness ratio (\%) obtained from the combined 2010 GlobeLand30 and 1:2000 GIS datasets reasonably reflects the greater imperviousness of urban areas and the urban center than is found in suburban and rural areas (Fig. 1).

Fig. 1

\subsection{Estimating the drainage flow capacity of the urban drainage system}

A drainage system is generally designed for effective discharge of the runoff and overflow produced by a storm with intensity defined by a certain return period (years) (Zhang et al. 2019). Here, a GIS road-network dataset is incorporated to derive the flow capacity of the drainage network. This is considered acceptable because roads in China are constructed parallel to sewage pipes, obeying the "Code for Urban Wastewater and Stormwater Engineering Planning" standards published by the Ministry of Housing and Urban-Rural Development (GB50318-2017 2017). The standards specify the design drainage flow capacities of the underground pipes based on the grade of the adjacent road (see Table 1). Thus, on the basis of rainfall intensity with a certain return period (years) (Zhang et al. 2019), the flow capacity of the drainage pipes can be determined indirectly by the road grades, which can be predetermined from the GIS mapping datasets. 
The urban areas connected hydraulically to the inlets and the route leading directly to a drainage system are considered to possess drainage flow capacities that influence runoff hydrograph estimates (Seo et al. 2013). For simplicity, these areas are assumed to project as GIS buffering zone objects along the drainage pipes parallel to the roads. In this hypothesis, the gridded drainage flow capacity $\left(D_{\text {cell }}\right)$ in a cell is deduced using the cell that intersects with these pipeline buffering zone objects:

$$
D_{\text {cell }}=\frac{\sum_{i=1}^{n} \operatorname{Inter} \operatorname{sect}\left(B(i), O_{\text {cell }}\right) \times D_{\text {buffer }}(i)}{A_{\text {cell }}},
$$

where Intersect $(B(i))$ is the GIS intersect operator used to calculate the intersect area of the $i$-th buffer $(B(i))$ and the cell $\left(O_{\text {cell }}\right), n$ is the number of buffers in the cell, $D_{\text {buffer }}(i)$ is the drainage capacity (yr) of the $i$-th pipeline buffering zone, and $A_{\text {cell }}$ is the cell area.

If a region intersects with no pipeline buffering zones, its drainage flow capacity is determined based on its local degree of urbanization. A typical urbanized residential area in China with population density of $>5000$ persons $/ \mathrm{km}^{2}$ should have storm sewerage infrastructure suitable for discharging the runoff produced by rainfall intensity with a return period of 1-3 (average: 1.5) years (GB50318-2000 2001); otherwise, it is considered a rural region with no urban sewerage system. Under these assumptions and in accordance with the standards, the cell drainage flow capacities are derived, which exhibit greater magnitude in more highly urbanized areas (see Fig. 2).

Although the simplified derivation somehow induces data uncertainty, it does promote low-cost model simulation (Pathirana et al. 2016). Critically, it is the only plausible approach for triggering this hydrological model in China. It differs from the object-oriented distributed urban drainage models in which the distributions of drainage facilities (e.g., wellheads, conduits, junctions, and outlets) must be recognized for running the hydrologic-hydrodynamic model. Such models can achieve more precise results (Fletcher et al. 2012; Aguilar et al. 2015; Tscheikner-Gratl et al. 2016; Broekhuizen et al. 2020) but are more expensive computationally and intricately assembled (Pathirana et al. 2016). 
Fig. 2

\section{Urban hydrological model}

Fig. 3

Fundamentally, the UHM comprises three steps: 1) rainfall to runoff estimation, 2) water flow channel path routing, and 3) hydraulic modeling (Fig. 3).

The ISA runoff $\left(R_{p}(1)\right)$ is simply the rainfall minus depression storage $\left(B_{g}\right)$ and evaporation $(E)$, whereas the PSA runoff $\left(R_{p}(2)\right)$ is mainly the Hortonian excess runoff, except for depression storage and evaporation. Thus, the total runoff of the cell is the sum of $R_{p}(1)$ and $R_{p}(2)$.

The D8 method obtains the slopes lines of the flow channel paths on the 30-m-resolution DEM. The gravity-driven streamflow crossing the clustered cells on the flow channel paths will lead to water stage changes that reflect the status of waterlogging and inundation in the cells. Additionally, the hydraulic Manning-Strickler equations are responsible for determination of the flow rate and volume.

\subsection{Surface runoff}

Surface depression storage comprises capillary storage and gravitational storage (Velásquez et al. 2020) and it varies as a function of LULC types that can be evaluated empirically (Table 2). Cell depression storage is area-weighted depending on the LULC type subareas of the cell:

$$
B_{g}=\sum_{i=1}^{n} 1_{i} \times B_{i}
$$

where $l_{i}$ is the area ratio of the $i$-th LULC type subarea to the containing grid cell, $n$ is the number of all LULC types of the grid cell, and $B_{i}$ is the depression storage of the $i$-th LULC type subarea.

In warm rainfall, runoff can be reduced slightly by evaporation, which also influences soil moisture and surface depression storage (Easton et al. 2007; Moreno et al. 2013). The submodel of the Common Land Model, published in Meng (2015) and 
cited herein regarding surface evaporation estimates, considers the effect of evapotranspiration of urban LULC on the production of runoff.

The ISA runoff $R_{p}$ is considered to be the rainfall $R$ minus depression storage and evaporation:

$$
\left\{\begin{array}{l}
R_{p}=R-B_{g}-E \quad R \geq B_{g}+E \\
R_{p}=0
\end{array} .\right.
$$

The Horton model is responsible for estimating infiltration $f$ on a pervious surface; consequently, PSA runoff $R_{p}$ is expressed as follows:

$$
\left\{\begin{array}{l}
R_{p}=R-B_{g}-E-f \quad R \geq B_{g}+E+f \\
R_{p}=0
\end{array} .\right.
$$

\subsection{Runoff discharged by the urban drainage system}

\subsubsection{Rainfall Intensity Estimates}

Synthetic rainfall data with a return period of nearly 10 years were simulated using the Chicago hyetograph method (Chen et al. 1998; Dai et al. 2014), on account of only deriving the maximum drainage flow capacity based on rainfall intensity with a 9-year return period (Fig. 2). The localized rainfall intensity, indicated by the rainfall rate $q(\mathrm{~mm} / \mathrm{min})$ in a certain return year rainfall $P(\mathrm{yr})$, is determined using the following rainstorm intensity formula (Hu 2016; Zhu et al. 2019):

$q=\frac{A_{1}(1+c \lg P)}{(t+B)^{\mathrm{n}}}$,

where $t$ is rainfall duration (min); and $A_{1}, B, c$, and $n$ are parameters related to the characteristics of the local rainstorm that need solutions (Zhu et al. 2019). However, the localized parameters $A_{1}, B, c$, and $n$ were referenced to the rainstorm intensity formula for the Beijing metropolis obtained from the "Water Supply and Drainage Design Manual Volume 5" published by the Beijing Municipal Planning Bureau (Table 4).

\subsubsection{Drainage Flow Capacity Estimates}

The drainage flow capacity is mostly determined by regional climatology, and it can be estimated using the following equation: 


$$
Q s=q^{\prime} \cdot \psi \cdot F
$$

where $Q s$ is the design drainage flow $\left(L \cdot S^{-1}\right)$ of the drainage system, $q^{\prime}$ is the design drainage flow capacity measured by rainfall intensity $\left(L \cdot S^{-1} \cdot h m^{-2}\right), \psi$ is the runoff coefficient, and $F$ is the catchment area $\left(h m^{2}\right)$.

The runoff coefficient $\psi$, which is used to regulate the rainfall to runoff magnitude and varies depending on LULC type (see Table 5). The runoff coefficient of the cell is also area-weighted, similar to using Eq. (2) for its calculation.

Assuming that

$$
\begin{aligned}
& Q s=q \cdot \psi \cdot F \quad(\psi=1) \\
= & q \cdot F
\end{aligned}
$$

means that the design drainage flow equal to the rainfall rate $q$, which will produce runoff on the catchment dimension $F$ with the maximum runoff coefficient $(\psi=1)$. Then, combining Eqs. (5)-(7):

$$
\begin{aligned}
& Q s=q \cdot F=q^{\prime} \cdot \psi \cdot F \\
& q^{\prime} \cdot \psi \cdot F=\frac{A_{1}(1+c \lg P)}{(t+B)^{\mathrm{n}}} F,
\end{aligned}
$$

gives

$$
q^{\prime}=\frac{A_{1}(1+c \lg P)}{\psi \cdot(t+B)^{\mathrm{n}}} .
$$

The ultimate runoff rate $r_{d}(\mathrm{~mm} / \mathrm{min})$ in an urban area is equal to the rate of runoff $\left(r_{s}\right)$ produced on the land surface (combining both impervious and pervious surfaces) subtracted from the design drainage flow capacity $q^{\prime}$, using Eq. (8):

$$
r_{d}=r_{s}-\frac{A_{1}(1+c \lg P)}{\psi \cdot(t+B)^{\mathrm{n}}} .
$$

\subsection{Hydraulic model}

\subsubsection{D8 Method to Route the Water Channel Paths}

The perception of streamflow within a channel network is based on a smoothing window combined with the D8 method (eight slope directions) used to determine the 
slope lines in a gridded DEM (Jenson and Domingue 1988). Slope lines, which are essential topographic attributes for the description of overland flows, provide both the flow paths along which gravity-driven nondispersive flows of water and sediment extend, and the skeleton around which dispersive overland flow patterns are likely to develop (Orlandini et al. 2014).

\subsubsection{Model Selection and Implementation}

The 1D hydraulic model is widely used in the distributed hydrological modeling for applications, i.e., the fluvial and pluvial flooding flood simulations (Bates and De Roo, 2000; Horritt and Bates, 2002; Zhu et al. 2019). However, it isn't suitable for modeling urban hydrology, counting for its incapability of taking into account of the dispersive overland flow patterns on urban floodplains where the multi direction flows are regular.

Nevertheless, the urban flood flow representation lies between diffusion wave and full dynamic equation. Most hydraulic models neglected the local acceleration, convective acceleration, and pressure terms in the momentum equation, and assumed that the friction and gravity forces balance (Pathirana et al. 2011; Abderrezzak et al. 2009; Bates and De Roo 2000). All these assumptions were admitted in the hydraulic modeling.

Based on the 1D to 2D St. Venant equation, the model is simplified to describe the depth-averaged 2D flow in the D8 method routing schemes. Therefore, the multiple flow direction (MFD) algorithms, in which each cell may contribute flow to multiple downslope neighbors (e.g., Quinn et al. 1991; Tarboton 1997), are introduced in formulating the urban dispersive flow patterns on the D8 method routing paths.

On this premise, the water volume changes in a cell when the upstream water inflows from the neighboring higher elevation cells which the number is $N(0<N<8)$, and the downstream water outflows to the lower elevation cells which the number is $N-8$; then, the water flux of the central cell 0 during the time step can be formulated to be: 


$$
\frac{d V}{d t}=\sum_{i=1}^{N} w_{i 0} Q_{i 0}+\sum_{j=N+1}^{8} w_{0 j} Q_{0 j}
$$

where $V$ is the cell volume $\left(L^{3}\right)$, and $Q_{i 0}$ and $Q_{0 j}$ are the inflow rates $\left(L^{3} T^{1}\right.$; positive for $Q_{i 0}$ and negative for $Q_{m 0}$ ) from cell $i$ to cell 0 and the outflow rates from cell 0 to cell $j$, respectively, in eight directions determined using the D8 method; $w_{i 0}$ and $w_{0 j}$ are the specified weights of the inflow rates from cell $i$ to cell 0 and the outflow rates from cell 0 to cell $j$, and determined by the following:

$$
\left\{\begin{array}{c}
\sum_{j=N+1}^{8} w_{0 j}=1 \\
w_{0 j}=\frac{S_{0 j}}{\sum_{i=N+1}^{8} S_{0 j}}
\end{array}\right.
$$

where $S_{0 j}$ is the slope between the cell 0 and cell $j$. The MFD determines the value of $w_{0 j}$, which the sum of one cell's multi direction outflows is 1. Meanwhile, in D8 flow routing scheme, a cell's flow passes to all downslope neighbors in proportion to slope. Note that the inflow weights $w_{i 0}$ can be regarded as the outflow weights of its $N$ adjacent cells, which can be achieved in the iterative computing over the cells when deducing outflow weights of these adjacent cells using Eq. (11).

The flow rate between cell $i$ and cell $j$ is determined using the Manning equation:

$$
Q_{i j}=\frac{A \cdot R^{\frac{2}{3}} \cdot S^{\frac{1}{2}}}{n},
$$

where $Q_{i j}$ is the flux $\left(L^{3} T^{-l}\right)$ between the two cells, $R$ is the hydraulic radius $(L)$ at the interface of the two cells, $S$ is the water surface slope between the two cells, and $n$ is the Manning's roughness coefficient $\left(T L^{-1 / 3}\right)$ (see Table 6), $A$ is the cell area.

The slope $S$ between two adjacent cells is expressed as follows:

$$
S=\frac{\Delta z}{l}
$$

where $\Delta z$ is the elevation difference between the two cells, and $l$ is the distance between the center points of the two cells, which depends on cell width $\Delta x \quad(l=\Delta x$ for orthogonal flow and $l=\sqrt{2} \Delta x$ for diagonal flow).

Assuming that the hydraulic radius and the mean water depth should be 
considered equivalently, the water flow velocity $U_{i j}$ can be expressed as the flow covering the distance through a cross-sectional area between the two cells ( $i$ and $j$ ) within a specific time:

$$
Q_{i j}=U_{i j} \cdot A
$$

The water flow velocity $U_{i j}$ can be calculated using Eqs. (12) and (14):

$$
U_{i j}=\frac{R^{\frac{2}{3}} \cdot S^{\frac{1}{2}}}{n} .
$$

When the water flow velocity is known, it is necessary to implement the Courant limitation (Pathirana et al. 2011) for time step $\Delta t$ to ensure the necessary stability during the simulation for the gridded cells using the 1D - 2D St. Venant equation:

$$
\left(\frac{\left|U_{i j}\right|+\sqrt{g d}}{\Delta x}\right) \Delta t \leq 1,
$$

where $\Delta t$ is the finite difference time step, $\Delta x$ is the distance between two adjacent cells, and $d$ is the water depth.

The model time step is constricted to ensure that it must be less than the Courant $\Delta t$ for each routing step for keeping computation stability and continuity (Caviglia and Dragani 1996; Pathirana et al. 2011).

\section{Case study of UHM simulation}

Before the model running, the parameter values of the LULC type area, design drainage flow capacity, elevation magnitude, and rainfall rate downscaled from the calibrated radar-derived QPEs/QPFs, etc., are evaluated and preserved in the 30-m spatial resolution cells properties. Bartsotas et al. (2017) suggested that using a model with higher spatiotemporal resolution should be a positive step in the field of flash flood forecasting. Additionally, the high-resolution cells in the hydrological model facilitate succinct determination of the flow routing channel paths and are convenient for derivation of water inundation mapping.

The model time step should adhere to the Courant limitation, and therefore the minimum Courant $\Delta t$ of all the cells on the water flow channel paths in the domain 
was calculated to be $2.425 \mathrm{~s}$ using Eq. (16). Thus, the time step is limited to $2 \mathrm{~s}$. Although the 2-s time step in model running requires considerable computational resources, it retains a conservative form of the St. Venant equations and continuity in the hydraulic process (Hodges 2019).

Benchmarking on the UHM launches the case study on the flash floods produced by extreme thunderstorms that occurred in Beijing on 21 July 2012 (the "7.21" rainstorm), details of which can be found elsewhere (e.g., Zhou et al. 2013; Chen et al. 2013; Hu et al. 2015; Zhang et al. 2015). The case study is performed to demonstrate the capability of the model in reproducing inundation mapping of flash flood events, which can be issued to severe weather warning and used in disaster prevention. Meanwhile, it investigates the impact of urbanization on urban hydrology by performing separate hydrological simulations for scenarios of pure imperviousness (PI), pure perviousness (PP), no drainage network (NDN), and the present LULC settings and drainage system configurations, presuming that all scenarios undergo the extreme " 7.21 " rainstorm.

As discussed earlier, verification of the model results with observational data remains a challenge, especially in terms of establishing a robust and acceptable hydrologic verification scheme (Welles et al. 2007). Amponsah et al. (2016) argued that hydrologic and geomorphic observations regarding extreme hydrogeomorphic processes are scarce owing to both the small spatiotemporal scale of flash flood occurrence, which limits the availability of hydrometeorological monitoring sites in impacted catchments, and the intensity of the runoff and geomorphic processes themselves, which limit the reliability of available stream gauge data and of postevent peak flood discharge estimates. Nevertheless, certain postevent information (e.g., from newspapers and Internet websites) regarding the flash floods that occurred following the "7.21" rainstorm has been collected for verification purposes (Fig. 4). The source of this information can be considered citizen science, which has been adopted previously in flash flood risk analysis, vulnerability assessment, and model validation (Assumpção et al. 2018; Sy et al. 2020).

Overpasses, crossroads and other junctions, and highways in the urban 
environment are reported susceptible to flash floods (Ogden et al. 2000), and therefore we paid particular attention to the model results relating to the inundation status (depths and dimensions) at such locations. Pictures and descriptions of the flooding at these places published in the media were also collected and compared with the geomorphologic characteristics overlapped by the model outputs for visual verification of the model results (Fig. 5).

\subsection{UHM simulation of the flash flooding that occurred on 21 July 2012}

Fig. 4

The model simulation reproduced the surface runoff, discharge, flow, and inundation mapping, addressing the flash flood magnitude as a time series on 21 July 2012 between 11:00 local time (LT) and 22:00 LT.

The simulation began at 11:00 LT. At 21:00 LT, the model results indicated that widespread flash flooding would occur in the Beijing metropolis with water inundation depths of $0.30-3.00 \mathrm{~m}$ (Fig. 4), consistent with the actual flash flooding experienced on that day. The model results indicated that the most likely flooding spots would be on the primary roads and at transportation facilities (Figs. 4 and 5). We checked the inundation mapping at over 12 locations considered highly susceptible to flooding (e.g., the Guangjumen overpass, Gongzhufan overpass, and Xikezhan overpass) and calculated the integrated maximum, minimum, and average inundation depths at these locations as 5.12, 0.06, and $2.22 \mathrm{~m}$, respectively, consistent with media reports. Meanwhile, the simulated flooding areas located in lower-lying land conformed to the distinctive geomorphological features denoted by the DEM contour lines (Fig. 5).

Fig. 5

\subsection{Sensitivity analysis}

The parameterization of LULC and drainage flow capacity in the model facilitates exploration of the hydrological response to LULC, which allows evaluation of both the impact of LULC change on flash flood intensity, and the reduction of 
flood intensity contributed by the drainage network. The simplified solution is to contrast the changes of flash flood intensity associated with the PI, PP, and NDN scenarios, in comparison with the actual flood intensity, when the model is forced by the "7.21" storm precipitation.

We defined the flash flood intensity index $F$ as follows:

$$
F=\int_{t 1}^{t 2} D(t) d t
$$

where $t_{1}$ is the inundation start time, $t_{2}$ is the end time ( $t_{2}-t_{1}$ is the duration), and $D(t)$ is the temporary water inundation depth at time $t$. The 2-s model time step can be the discrete time interval for Eq. (18).

The ratio of the simulated flood intensity $F_{s}$ in each of the scenarios to the actual flood intensity $F_{a}$ is taken as the sensitivity index $S$ :

$$
S=\frac{F_{s}}{F_{a}} .
$$

The 12 overpasses most susceptible to flash flooding (listed in the x-axis of Fig. 6) were selected for the sensitivity test. After each model time step, the inundation depth at each location was output for calculation of the flood intensity $F_{\mathrm{s}}$ (using Eq. (18)) under the PI, PP, and NDN scenarios, which was obtained by controlling the LULC parameter (setting the ISA percentage to $100 \%$ and $0 \%$ for the PI and PP scenario, respectively) and the design drainage flow capacity $q^{\prime}$ (setting $q^{\prime}=0$ for the NDN scenario).

Although the simulated flood intensities under the PI scenario at the 12 overpasses are largely enhanced in comparison with the actual flood intensities, the magnitudes of the enhancement are $<30 \%$ and thus are not considered prominent (Fig. 6). Given that the 12 overpasses are distributed in highly urbanized areas where the minimum imperviousness is $88 \%$, it could be assumed that changing the LULC setting to pure imperviousness would not lead to an extraordinary enhancement in flood intensity. Note that the flood intensity at the Hangtianqiao and Liuliqiao overpasses would be slightly inversely attenuated $(-3 \%)$ under the $100 \%$ imperviousness scenario. It would be in the case that the reduced land surface roughness induced by the impervious in such watersheds or outlets accelerated 
draining out the waterloggings and facilitating the runoffs to overflow downstream and/or into the adjacent watersheds.

Under the NDN scenario, the flash flood intensity would be enhanced by $30 \%-60 \%$, reflecting the important role of a drainage system with regard to mitigation of urban flash flooding. A slight exception can be discerned at the Guangjumen overpass, that is, the NDN scenario produces enhancement of approximately only $3 \%$ in terms of flash flood intensity. The drainage flow capacity estimates (not shown) indicate that the designed drainage capacity at the Guangjumen overpass is to drain the runoff associated with a nearly 1-year return period rainstorm. Moreover, the region occupies $3 \%$ of the wetted river surface, that is, higher than the average level of $0.8 \%$. Maybe, the rainfall producing runoff flow conveniently into the nearby river, and the local drainage network will play a minor role in surface water discharge.

In contrast to the above, given the high degree of urbanization of the studied locations, the effect of the pure previousness on the flood intensity attenuation would be very distinctive. The simulation indicates that, under the PP scenario, the flood intensities at the studied locations would be reduced by approximately $50 \%-90 \%$ (Fig. $6)$.

It can be concluded that improving the drainage network and increasing the degree of perviousness in the urban environment could be the two measures most effective for urban flash flood risk reduction. These measures have been identified in China as the "the straw for life" in building "sponge cities" (e.g., Yong et al. 2018; Yin et al. 2021). However, the implementation would be very challenging, and especially the increasing of urban perviousness would be far more impracticable than updating the drainage system, owing to the extraordinary expense associated with imperviousness reclamation.

Fig. 6

\section{Summary}

This study developed a two-dimensional raster gridded UHM (driven by the 1D - 
2D St. Venant equation) to simulate the hydrologic response to urban land surfaces and urban hydraulic characteristics, which is desirable in relation to the issuance of warnings regarding the urban flash flood occurrence. Forced by radar-derived QPEs, the UHM simulation satisfactorily reproduced the urban flash flooding that occurred following the " 7.21 " rainstorm event.

The model results were somewhat verified based on the degree of resemblance to the actual scenario described by media reports. Thus, the model was considered suitable for testing the sensitivity of flash flood intensity to urban LULC variability and the drainage network capacity. The primary findings were as follows.

1) Given the degree of saturated imperviousness in urban areas, flood intensity enhancement under the PI scenario would not be prominent.

2) The flood intensity under the PP scenario at the studied locations considered most susceptible to flooding could be reduced by $50 \%-90 \%$.

3) The urban drainage network plays an important role in flash flood mitigation; under the NDN scenario, flash flood intensity would be enhanced by $30 \%-60 \%$.

The above findings might appear to reflect commonsense, and however it indirectly demonstrates the validation of the hydrological model simulation. Moreover, validation of the model reproducibility in relation to the flash flood occurrence was at least partially confirmed in terms of scale and intensity by checking the 12 sample sites considered most susceptible to flash flooding in the case study. It must be acknowledged that the model simplicity, modeling assumptions, lack of data, indirect data derivation, and inadequate parameterization mean that there is considerable scope for improvement of the UHM in terms of robustness and accuracy regarding the reproduction of the flash flood occurrence. Moreover, in future work, it will be exciting to force the model using QPFs or qualified QPFs, rather than radar-derived QPEs, to produce flash food mapping in advance for risk perception and flash flood forecasts. It should be noted that QPFs have larger biases in terms of rainfall magnitude and location; however, they are more applicable in relation to severe weather warnings owing to their recognized suitability for forecasts of 1, 3, and $6 \mathrm{~h}$ ahead. Although further challenges remain, this work clearly indicates that the field of 
urban flash flood forecasting is progressing in the right direction.

\section{Acknowledgements}

This study has been supported by Chinese Academy of Sciences Key Technology Talent Program (Project: 2019YFB2102901).

\section{References}

Abderrezzak, K. E. K., A. Paquier, E. Mignot, 2009: Modelling flash flood propagation in urban areas using a two-dimensional numerical model. Nat Hazards, 50:433-460, DOI 10.1007/s11069-008-9300-0.

Allen, M. R. and Ingram,W. J., 2002: Constraints on future changes in climate and the hydrologic cycle, Nature, 419 (12), 223-231.

Amponsah, W., L. Marchi, D. Zoccatelli, G. Boni, M. Cavalli, F. Comiti, S. Crema, A. LUCÍA, F. Marra, and M. Borga, 2016: Hydrometeorological Characterization of a Flash Flood Associated with Major Geomorphic Effects: Assessment of Peak Discharge Uncertainties and Analysis of the Runoff Response. J. Hydrometeor., 17, 3063-3077.

Anagnostou, E. N., W. F. Krajewski, D. J. Seo, and E. R. Johnson, 1998: Mean-field rainfall bias studies for wsr-88d, J. Hydrol. Eng., 3(3), 149-159.

Assumpção, T. H., I. Popescu, A. Jonoski, and D. P. Solomatine, 2018: Citizen observations contributing to flood modelling: opportunities and challenges, Hydrol. Earth Syst. Sci., 22, 1473-1489, https://doi.org/10.5194/hess-22-1473-2018, 2018.

Barthold, F. E., T. E. Workoff, B. A. Cosgrove, J. J. Gourley, D. R. Novak, and K. M. Mahoney, 2015: Improving Flash Flood Forecasts: The HMT-WPC Flash Flood and Intense Rainfall Experiment. Bull. Amer. Meteor. Soc., 96, 1859-1866, DOI:10.1175/BAMS-D-14-00201.1. Bartsotas, N. S., E. I. Nikolopoulos, E. N. Anagnostou, S. Solomos, G. Kallos, 2017: Moving toward Subkilometer Modeling Grid Spacings: Impacts on Atmospheric and Hydrological Simulations of Extreme Flash Flood-Inducing Storms. J. Hydrometeor., 18, 209-226. 
Bates, P. D. and De Roo, A. P. J.: A simple raster-based model for flood inundation simulation, J. Hydrol., 236, 54-77, https://doi.org/10.1016/S0022-1694(00)00278-X, 2000.

Beighley, R. E., and G. E. Moglen, 2003: Adjusting measured peak discharges from an urbanizing watershed to reflect a stationary land use signal, Water Resour. Res., 39(4), 1093, doi:10.1029/2002WR001846.

Borga, M., P., Boscolo, F. Zanon, and M., Sangati, 2007: Hydrometeorological Analysis of the 29 August 2003 Flash Flood in the Eastern Italian Alps. J. Hydrol., 8, 1049-1067.

Bowling, L.C., P. Storck, and D.P. Lettenmaier, 2000: Hydrologic effects of logging in western Washington, United States. Water Resour. Res. 36, 3223-3240.

Burke, C., P. Stott, Y. Sun, and A. Ciavarella, 2016: Attribution of Extreme Rainfall in Southeast China During May 2015. BAMS, 97(2): S92-S96.

Ciach, G. J., W. F. Krajewski, E. N. Anagnostou, M. L. Baeck, J. A. Smith, J. R. McCollum, and A. Kruger, 1997: Radar rainfall estimation for ground validation studies of the tropical rainfall measuring mission, J. Appl. Meteorol., 36(6), 735-747.

Chen, J., Chen, J., Liao, A., Cao, X., Chen, L., Chen, X., He, C., Han, G., Peng, S., Lu, M., Zhang, W., Tong, X., \& Mills, J., 2014: Global land cover mapping at 30 resolution: A POK-based operational approach. ISPRS Journal of Photogrammetry and Remote Sensing, 103, 7-27.

Chen, M., Y. Wang, X. Xiao, F. Gao. 2013. Initiation and propagation mechanism for the Beijing extreme heavy rainstorm clusters on 21 July 2012. Acta Meteorologica Sinica, 71(4): 569-592.

Easterling, D.R., G..A. Meehl, C. Parmesan, S. A. Changnon, T.R. Karl, and L.O. Hearns, 2000: Climate extremes: Observations, modeling and impacts. Science, 289, 2068-2074.

Easton, Z. M., P. Ge'rard-Marchant, M. T. Walter, A. M. Petrovic, and T. S. Steenhuis, 2007: Hydrologic assessment of an urban variable source watershed in the northeast United States, Water Resour. Res., 43, W03413, doi:10.1029/2006WR005076.

Graf, W. L., 1977: Network characteristics in suburbanizing streams, Water Resour. Res., 13, 459-463, doi:10.1029/WR013i002p00459.

GB50318-2000 - Code of Urban Wastewater Engineering planning. Standards of People's Republic of China, Beijing, China, 2001.

Gourley, J. J., and B. E. Vieux, 2005: A method for evaluating the accuracy of quantitative precipitation estimates from a hydrologic modeling perspective, J. Hydrometeorol., 6(2), 115-133. 
Haberlandt, U., 2007: Geostatistical interpolation of hourly precipitation from rain gauges and radar for a large-scale extreme rainfall event, J. Hydrol., 332(1-2), 144-157.

He, X., T. O. Sonnenborg, J. C. Refsgaard, F. Vejen, and K. H. Jensen., 2013: Evaluation of the value of radar QPE data and rain gauge data for hydrological modeling. Water Resour. Res., 49, 5989-6005, doi:10.1002/wrcr.20471.

Hu, H. B., X. Liang, F. You, J. Sun, 2015: Analysis of meteorological services under extreme weather conditions based on a Bayesian decision-support model: a case study of the thunderstorms in Beijing on July 21, 2012.Natural hazards, 2015 , 78 (2) :1225-1241.DOI 10.1007/s11069-015-1766-y.

Hu, H. B. 2016. Research progress of surging urban flood risks. Progress in Geography, 35(9): 1075-1086. DOI: 10.18306/dlkxjz.2016.09.003. (in Chinese)

IPCC (Intergovernmental Panel on Climate Change) (2007) Climate change 2007: the physical science basis. contribution of working group I to the fourth assessment report of the intergovernmental panel on climate change. Cambridge University Press, Cambridge.

Kotowski, A., and B. Kazmierczak, 2013: Probabilistic Models of Maximum Precipitation for Designing Sewerage. J. Hydrometeor., 14, 1958-1965.

Li, X., S. Erpicum, M. Bruwier, E. Mignot, P. Finaud-Guyot, P. Archambeau, M. Pirotton, and B. Dewals, 2019: Technical note: Laboratory modelling of urban flooding: strengths and challenges of distorted scale models. Hydrol. Earth Syst. Sci., 23, 1567-1580, https://doi.org/10.5194/hess-23-1567-2019.

Meng, C., 2009: Land surface temperature data assimilation and its impact on evapotranspiration estimates from the Common Land Model. Water Resour. Res., 45 (14) :335-345.

Morneno, H. A., E. R. Vivoni, D. J. Gochis, 2013: Limits to Flood Forecasting in the Colorado Front Range for Two Summer Convection Periods Using Radar Nowcasting and a Distributed Hydrologic Model. J. HydroMeteor., 14, 1075-1097.

Ogden, H. O. Sharif, S. U. S. Senarath, J. A. Smith, M. L. Baeck, and J. R. Richardson, 2000: Hydrometeorological analysis of the Fort Collins, Colorado, flash flood of 1997. J. Hydrol.,228, $82-100$.

Ogden, F. L., N. R. Pradhan, C. W. Downer, and J. A. Zahner, 2011: Relative importance of impervious area, drainage density, width function, and subsurface storm drainage on flood runoff 
from an urbanized catchment. Water Resour. Res., 47, W12503, doi:10.1029/2011WR010550, 2011.

Oldenborgh, G. J. V., F. E. L. Otto, K. Haustein, and K. AchutaRao, 2016: The Heavy Precipitation Event of December 2015 in Chennai, India. Bull. Amer. Meteor. Soc., 97(2): S87-S91.

Orlandini, S., G. Moretti, and A. Gavioli, 2014: Analytical basis for determining slope lines in grid digital elevation models. Water Resour. Res., 50, 526-539, doi:10.1002/2013WR014606.

Pathirana, A., S. Tsegaye, B. Gersonius, and K. Vairavamoorthy. A simple 2-D inundation model for incorporating flood damage in urban drainage planning. Hydrol. Earth Syst. Sci., 15, 2747-2761, 2011. doi:10.5194/hess-15-2747-2011

Pielke R A, Adegoke J, Beltran-Przekurat A, Hiemstra C. A., Lin J., Nair U. S., D. Niyogi and T. E. Nobisi, 2007: An overview of regional land use and land cover impacts on rainfall. Tellus, 59(3): 587-601.

Quinn, P., K. Beven, P. Chevallier, and O. Planchon, 1991: The prediction of hillslope flow paths for distributed hydrological modelling using digital terrain models, Hydrol. Processes, 5(1), 59-79, doi:10.1002/hyp.3360050106.

Seo, D. J., and J. P. Breidenbach, 2002: Real-time correction of spatially nonuniform bias in radar rainfall data using rain gauge measurements. J. Hydrometeor., 3(2), 93-111.

Sharif, H. O., D., Yates, R., Roberts, and C. Mueller, 2006: The Use of an Automated Nowcasting System to Forecast Flash Floods in an Urban Watershed. J. Hydrometeor., 7(1):190-202.

Shepherd,J.M., and S.J. Burian, 2003: Detetion of urban-induced rainfall anomalies in a major coastal city. Earth Interactions, 7.

Shepherd,J.M., 2005: A review of current investigations of urban-induced rainfall and recommendations for the future. Earth Interactions,7.

Siswanto, G. J. V. Oldenborgh, G. V. D. Schrier, G. Lenderink,and B.V. D. Hurk, 2015: Trends in High-daily Precipitation Events in Jakarta and the Flooding of January 2014.BAMS, 96(12), S131-S135.

Smith, J. A., and W. F. Krajewski, 1991: Estimation of the mean field bias of radar rainfall estimates, J. Appl. Meteorol., 30(4), 397-412.

Smith, J. A., M. L. Baeck, J. E. Morrison, P. Sturdevant-Rees, D. F. Turner-Gillespie, and P. D. 
Bates, 2002: The regional hydrology of extreme floods in an urbanizing drainage basin, J. Hydrometeorol., 3(3), 267-282.

Smith, J. A., M. L. Baeck, K. L. Meierdiercks, P. A. Nelson, A. J. Miller, and E. J. Holland, 2005a: Field studies of the storm event hydrologic response in an urbanizing watershed, Water Resour. Res., 41, W10413, doi:10.1029/2004WR003712.

Smith, J. A., A. J. Miller, M. L. Baeck, P. A. Nelson, G. T. Fisher, and K. L. Meierdiercks, 2005b: Extraordinary flood response of a small urban watershed to short duration convective rainfall, J. Hydrometeorol., 6(5), 599-617.

Smith, M. L., Baeck, G. Villarini, C. Welty, A. J. Miller, and W. Krajewski, 2012: Analyses of a long-term high-resolution radar rainfall data set for the Baltimore metropolitan area. Water Resour. Res., 48, W04504, doi:10.1029/2011WR010641

Sy, B., C. Frischknecht, H. Dao, D. Consuegra, and G. Giuliani. Reconstituting past flood events: the contribution of citizen science.Hydrol. Earth Syst. Sci., 24, 61-74, 2020.https://doi.org/10.5194/hess-24-61-2020

Steiner, M., R. A. Houze, and S. E. Yuter, 1995: Climatological characterization of 3-dimensional storm structure from operational radar and raingauge data, J. Appl. Meteorol., 34(9), 1978-2007.

Tarboton, D. G., 1997: A new method for the determination of flow directions and upslope areas in grid digital elevation models, Water Resour. Res., 33(2), 309-319, doi:10.1029/96WR03137.

Turner-Gillespie, D. F., J. A. Smith, and P. D. Bates, 2003: Attenuating reaches and the regional flood response of an urbanizing drainage basin, Adv. Water Resour., 26, 673-684.

Velásquez, N., C. D. Hoyos, J. I. Vélez, and E. Zapata. Reconstructing the 2015 Salgar flash flood using radar retrievals and a conceptual modeling framework in an ungauged basin. Hydrol. Earth Syst. Sci., 17, 3473-3483, 2013. doi:10.5194/hess-17-3473-2013

Villarini, G., F. Serinaldi, and W. F. Krajewski, 2008: Modeling radar rainfall estimation uncertainties using parametric and non-parametric approaches, Adv. Water Resour., 31(12), $1674-1686$.

Wolter, K., M. Hoerling, J. K. Eischeid, and L. Cheng, 2016: What History Tells us About 2015 U. S. Daily Rainfall Extremes. Bull. Amer. Meteor. Soc., 97(2): S9-S13.

Wright, D. B., J. A. Smith, G. Villarini, and M. L. Baeck, 2012: The hydroclimatology of flash 
flooding in Atlanta. Water Resour. Res., 48, W04524, doi:10.1029/2011WR011371.

van de Beek, C. Z., H. Leijnse, J. N. M. Stricker, R. Uijlenhoet, and H. W. J. Russchenberg, 2010: Performance of high-resolution x-band radar for rainfall measurement in the Netherlands, Hydrol. Earth Syst. Sci., 14(2), 205-221.

Yang, G. X., and L. C.Bowling, K. A. Cherkauer et al. , 2010: Hydroclimatic response of watersheds to urban intensity: An observational and modeling-based analysis for the white river basin, Indiana. J. Hydrom., 11,121-138.

Yang, L., J. A. Smith, D. B. Wright, M. L. Baeck, G. Villarini, F. Tian and H. Hu, 2013: Urbanization and Climate Change: An Examination of Nonstationarities in Urban Flooding. J. Hydrometeror., 14, 1791-1809.

Yin, D., Y. Chen, H. Jia, Q. Wang, Z. Chen, C. Xu, Q. Li, W. Wang, Y. Yang, G. Fu, A. S. Chen. 2021: Sponge city practice in China: A review of construction, assessment, operational and maintenance, Journal of Cleaner Production, Volume 280, Part 2, 2021, 124963. https://doi.org/10.1016/j.jclepro.2020.124963.

Yong, J., Zevenbergen, C. , Ma, Y., 2018: Urban pluvial flooding and stormwater management: A contemporary review of China's challenges and "sponge cities" strategy. Environmental Science and Policy, 80:132-143, https://doi.org/10.1016/j.envsci.2017.11.016.

Zhang, Y., Y. Hong, X. Wang, J. J. Gourley, X. Xue, M. Saharia, G. Ni, G. Wang, Y. Huang, S. Chen, and G. Tang, 2015: Hydrometeorological Analysis and Remote Sensing of Extremes: Was the July 2012 Beijing Flood Event Detectable and Predictable by Global Satellite Observing and Global Weather Modeling Systems?. J. Hydrometeor. 16, 381-395.

Zhou, T., F. Song, R. Lin, et al., 2013 : The 2012 north china floods : explaining an extreme rainfall event in the context of a longer -term drying tendency[J]. Bull. Amer. Meteor. Soc., S49-S52.

Zhu, X., Q. Dai, D. Han, L. Zhuo, S. Zhu, and S. Zhang. Modeling the high-resolution dynamic exposure to flooding in a city region.Hydrol. Earth Syst. Sci., 23, 3353-3372, 2019. https://doi.org/10.5194/hess-23-3353-2019 

Table 1. List of drainage flow capacity of roadside pipes corresponding to road grade (map scale of 1:2000)

Table 2. Depression storage $B_{i}(\mathrm{~mm})$ of different land use/cover types

Table 3. Parameter values for the rainfall intensity formula

Table 4. Runoff coefficients of land use/cover type areas

Table 5. Model parameters for different land use/cover types (Ogden et al. 2011) 
Table 1. List of drainage flow capacity of roadside pipes corresponding to road grade (map scale of 1:2000)

\begin{tabular}{lcc}
\multicolumn{1}{c}{ Road in grades } & Code & \multicolumn{2}{c}{ Drain flow capacity measured by } \\
return-period (years) rainfall intensity
\end{tabular}


Table 2. Depression storage $B_{i}(\mathrm{~mm})$ of different land use/cover types

\begin{tabular}{|c|c|}
\hline Land use/cover types & Depression storage $\boldsymbol{B}_{\boldsymbol{i}}{ }^{\prime} \mathbf{( m m )}$ \\
\hline Pervious areas & 5.0 \\
\hline Impervious areas & $1.27-2.54$ \\
\hline Industrial areas & 1.4 \\
\hline Public commercial areas & 1.4 \\
\hline Residential (lawns) & $2.54-5.08$ \\
\hline Forest & 7.62 \\
\hline
\end{tabular}


Table 3. Parameter values for the rainfall intensity formula

\begin{tabular}{|l|l|l|l|l|}
\hline Selection & $\boldsymbol{A}_{\boldsymbol{I}}$ & $\boldsymbol{B}$ & $\boldsymbol{c}$ & $\boldsymbol{n}$ \\
\hline Average in years & 14.688 & 13.8 & 0.761 & 0.739 \\
\hline Maximum in years & 11.442 & 12.6 & 0.891 & 0.708 \\
\hline
\end{tabular}


Table 4. Runoff coefficients of land use/cover type areas

\begin{tabular}{ll}
\hline Land use/cover types & Runoff coefficients \\
\hline Every roofing, concrete and asphalt pavement & $0.85-0.95$ \\
\hline Stones pavement and asphalt surfaced chippings pavements & $0.55-0.65$ \\
\hline Trivial chippings pavement & $0.40-0.50$ \\
\hline Placed rockfill pavement & $0.35-0.45$ \\
\hline Soil surface & $0.25-0.35$ \\
\hline Green belt & $0.10-1.20$ \\
\hline
\end{tabular}


Table 5. Model parameters for different land use/cover types (Ogden et al. 2011)

\begin{tabular}{llll}
\hline \multicolumn{2}{c}{ Land use/cover types } & $\begin{array}{c}\text { Manning's roughness } \\
\text { coefficients }\end{array}$ & $\begin{array}{c}\text { Depression storage } \\
(\mathbf{m m})\end{array}$ \\
\hline Impervious & Industrial land use & 0.02 & 1.4 \\
surface & Commercial land & 0.014 & 1.4 \\
areas & use & & \\
& Pipes & 0.035 & 1 \\
& Others & 0.02 & 1.3 \\
Pervious & Residential lawns & 0.20 & 5.0 \\
surface & Other vegetated & 0.014 & 5.0 \\
areas & areas & & \\
\hline
\end{tabular}


Fig. 1. Distribution of imperviousness ratio (\%) in urban, suburban, and rural areas of Beijing.

Fig. 2. Distribution of drainage flow capacity (generalized from GIS data) in urban, suburban, and rural areas of Beijing.

Fig. 3. Illustrative diagram of the methodologies adopted in the UHM.

Fig. 4. Distribution of locations of severe flash flooding in Beijing reported by the mainstream media and social media following the 21 July 2012 rainstorm.

Fig. 5. Simulated inundation mapping at (a) the Guangjumen overpass, (b) Lianhuaqiao overpass, and (c) Liuliqiao overpass following model integration to 21:00 LT, overlain with landscape imagery, isohypse lines, and corresponding pictures of the actual flooding taken by the media.

Fig. 6. Simulated sensitivity index values (y-axis) at 12 overpasses most susceptible to flash flooding ( $x$-axis) under the PI (blue bars), PP (yellow bars), and NDN (purple bars) scenarios. 


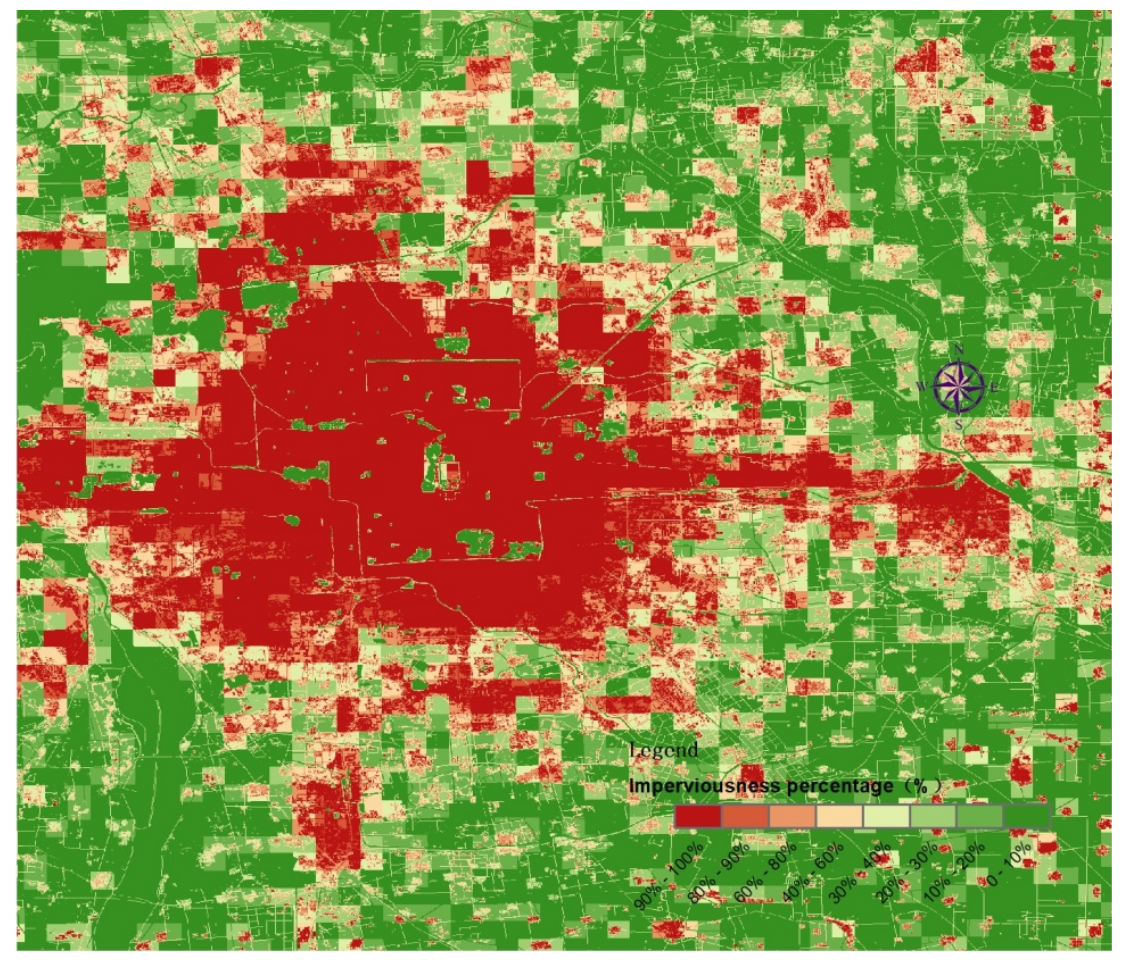

Fig. 1. Distribution of imperviousness ratio (\%) in urban, suburban, and rural areas of Beijing. 


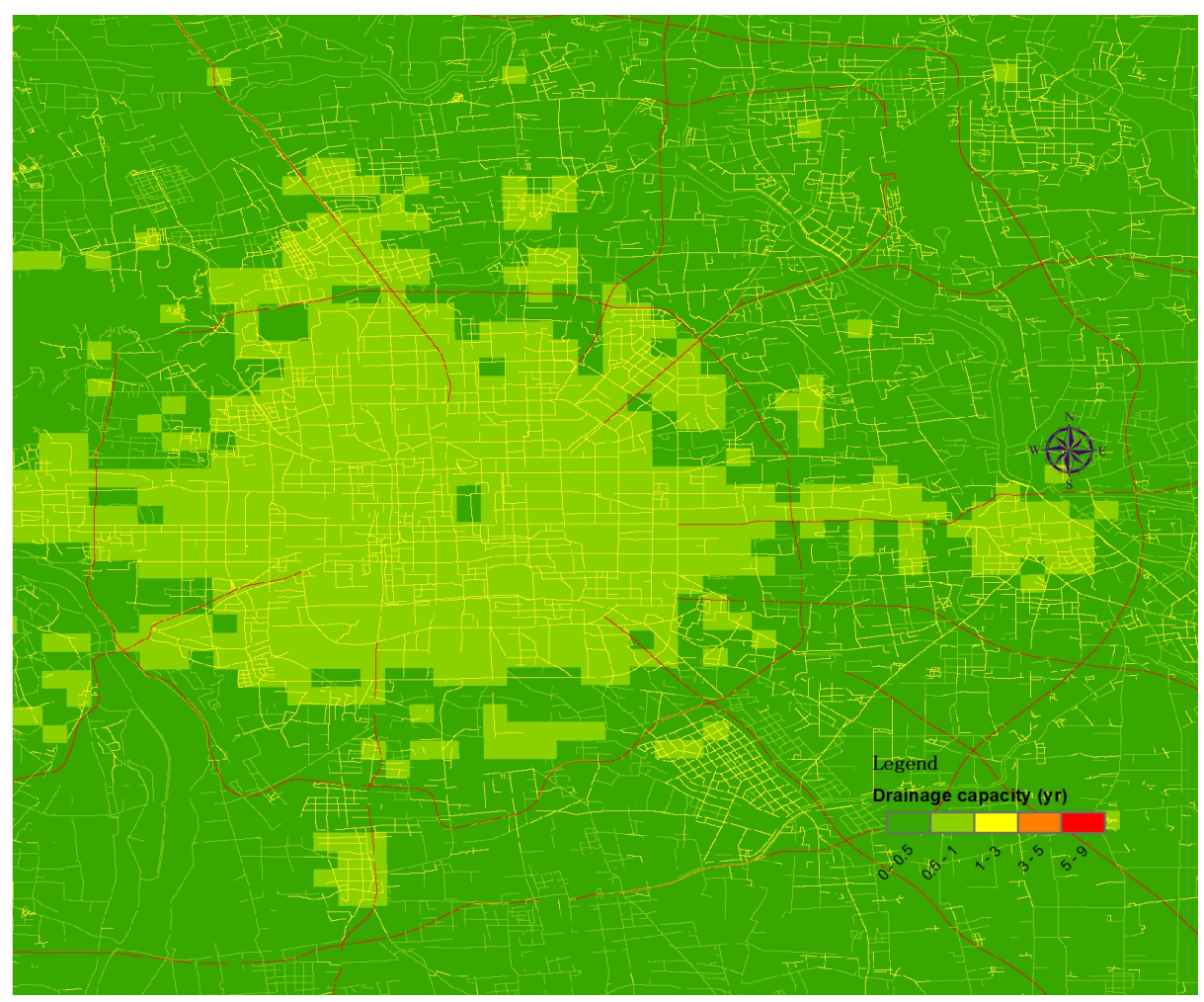

Fig. 2. Distribution of drainage flow capacity (generalized from GIS data) in urban, suburban, and rural areas of Beijing. 


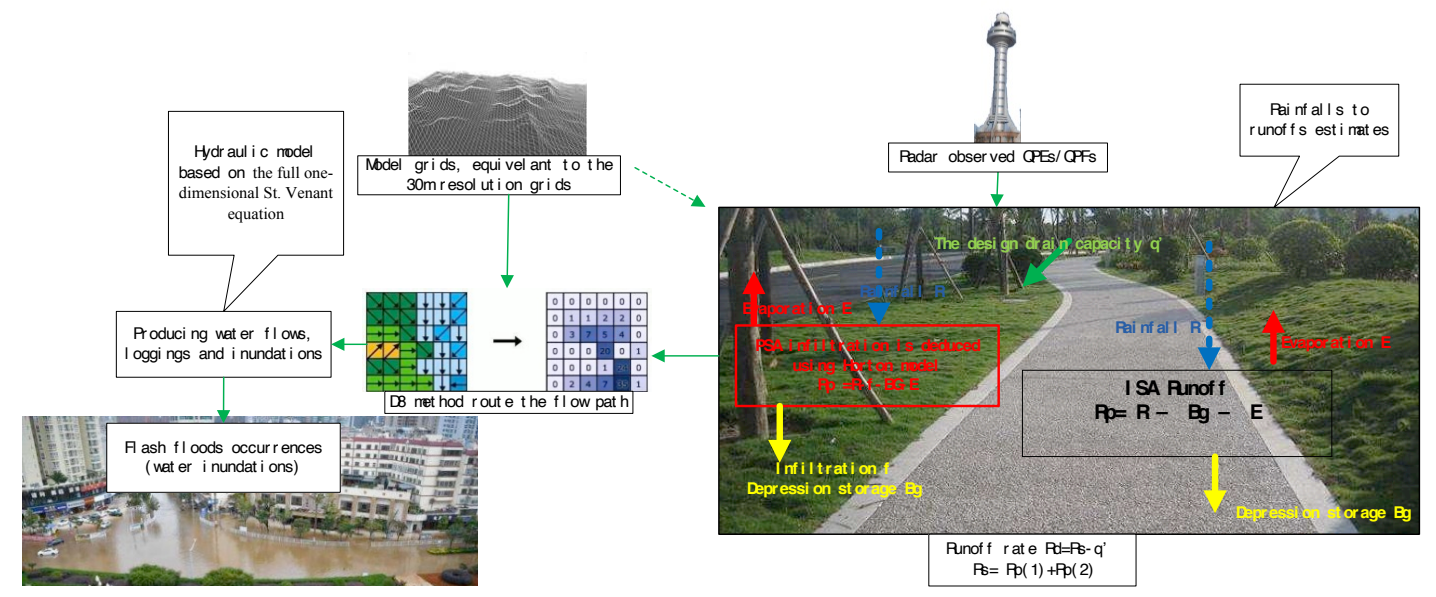

Fig. 3. Illustrative diagram of the methodologies adopted in the UHM. 


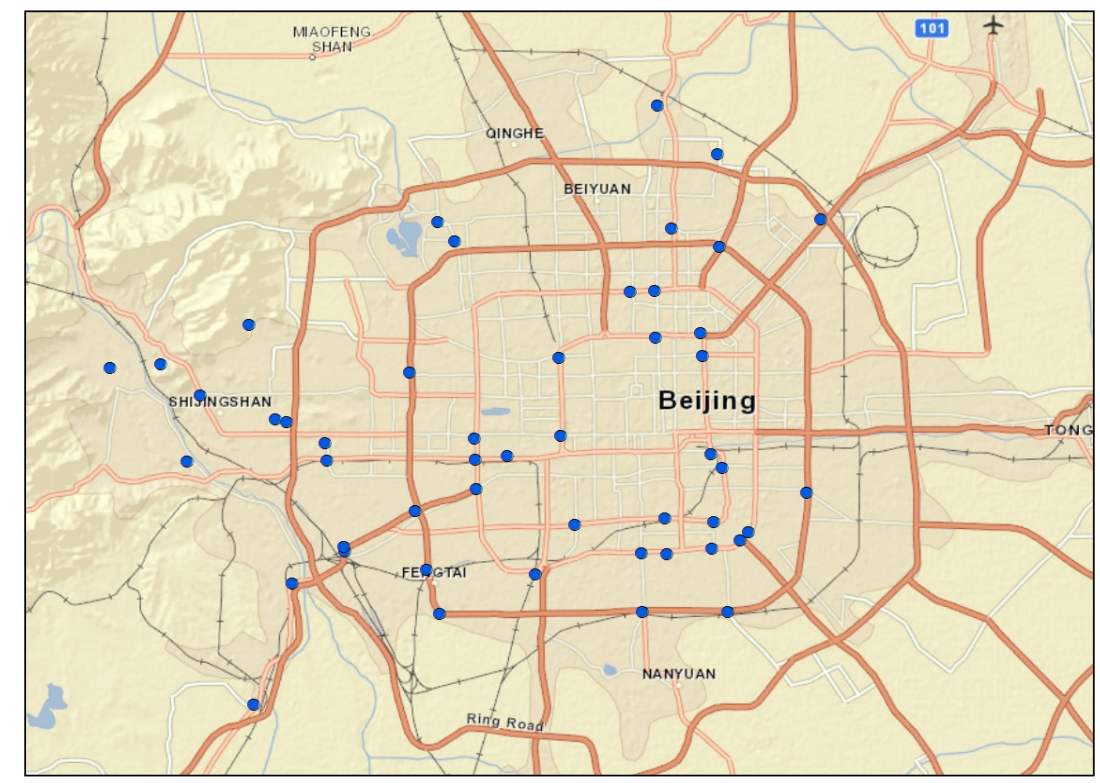

Fig. 4. Distribution of locations of severe flash flooding in Beijing reported by the mainstream media and social media following the 21 July 2012 rainstorm. 

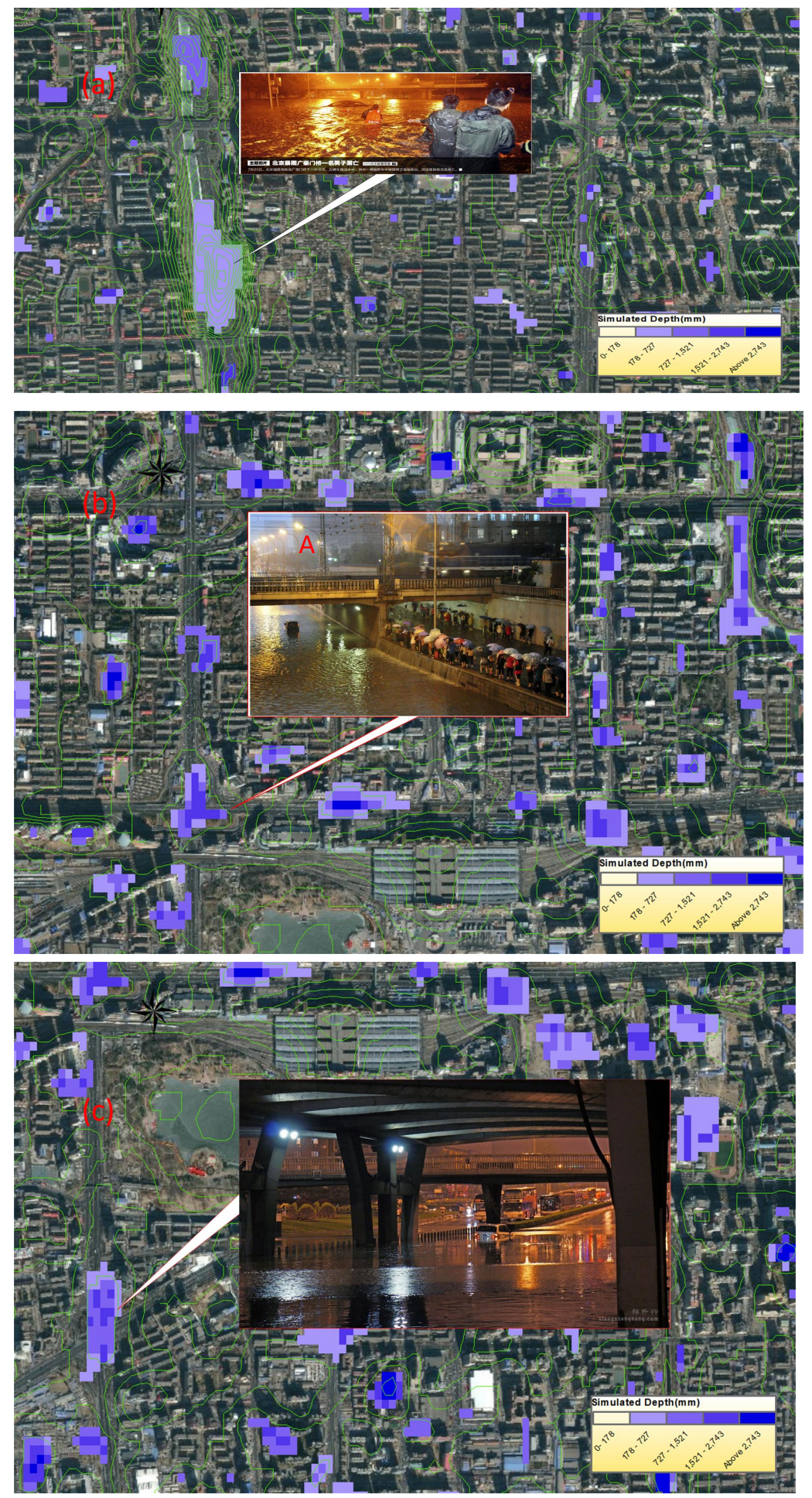

Fig. 5. Simulated inundation mapping at (a) the Guangjumen overpass, (b) Lianhuaqiao overpass, and (c) Liuliqiao overpass following model integration to 21:00 LT, overlain with landscape imagery, isohypse lines, and corresponding pictures of the actual flooding taken by the media. All these mappings are displayed in the software of ArcMap 9.2. 


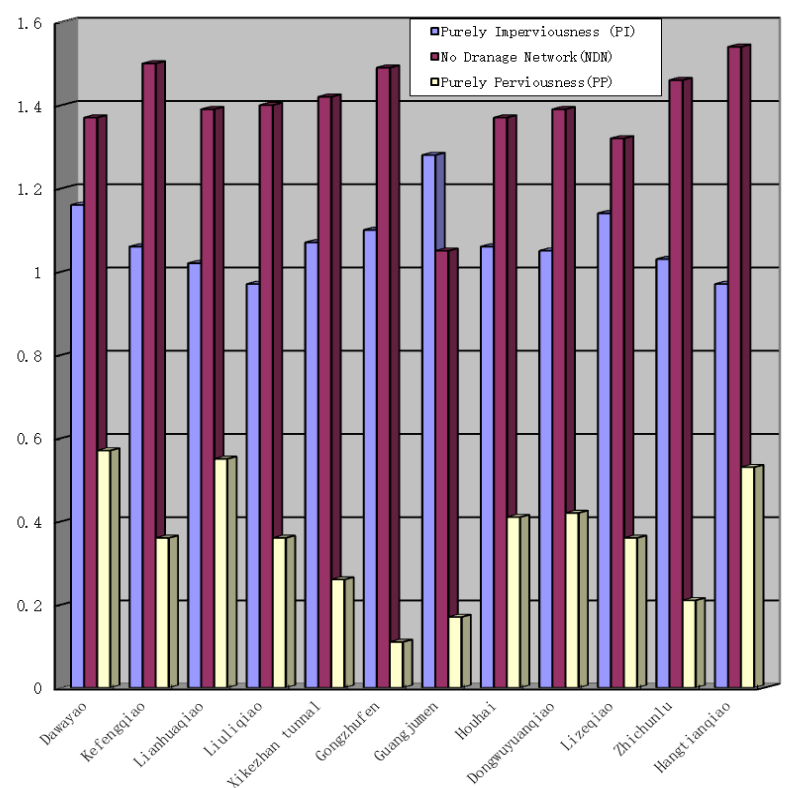

Fig. 6. Simulated sensitivity index values ( $y$-axis) at 12 overpasses most susceptible to flash flooding ( $x$-axis) under the PI (blue bars), PP (yellow bars), and NDN (purple bars) scenarios. 